\title{
Mechanistic individualism versus organistic totalitarianism
}

\author{
J.J. Venter \\ Department of Philosophy \\ Potchefstroom University for CHE \\ POTCHEFSTROOM
}

\begin{abstract}
Mechanistic individualism versus organistic totalitarianism

In this article it is argued that the organistic world picture, when functioning as a world view, is associated with a totalitarian view of social relationships, usually promoting the interests of the state or the ethnic group as the interests which should dominate. This is illustrated by referring to the social ideas of Hobbes, Rousseau, D.H. Lanrence and Mussolini. The mechanistic world picture, however, when functioning as a world view, is associated with individualism, according to which the individuals have a relatively independent existence; it suggests that justice and morality are the automatic products of the equilibrating process. Cases in point: Hobbes, Adam Smith, Kant, Danvin. New-Classical and Monetarist economics. Finally (in Neo-Calvinist vein) it is argued that the application of such worldviewish metaphors should be limited, so that justice can be done to both the differentiation of social relationships and their integration
\end{abstract}

\section{Background}

Main thesis: Each extreme of social thinking, individualism and totalitarianism bases itself on some idea of ultimate reality: individualism is associated with a mechanistic picture of the universe (applied to social life), and totalitarianism with an organistic picture of the universe. Such pictures become or are world views which determine and give meaning to the behaviour of persons toward aspects of the world interpreted in terms of these pictures (in casu social reality), i.e. these pictures determine what reality "in essence" is, in totality and in detail (even when the picture itself is acknowledged to be a metaphor).

It seems as if human beings, as beings with self-consciousness, continually retum to the question of "the meaning of life". Why do I live at all? Why shouldn't we all commit suicide? Who am I with regard to other self-conscious beings? Why expect different behaviour from me than from lions? Pictures of the universe play 
an orientating role with regard to such questions: they provide metaphorical explanations of "macrocosmic" patterns; they also provide maps which guide human beings through life, and relate the individual human being to other possible beings, giving mankind a status and some aims. They can also serve to explain the peculiarities of social structures and the relationship of the individual towards them.

Although one can possibly picture the universe in an infinite number of ways, two pictures seem to have dominated Westem thought: an ancient one, according to which the universe is a living being (the organistic picture); and a modern one, dating from the seventeenth century, viewing the universe as a machine (the mechanistic one).

Ancient people had no other way of explaining the movements of heavenly bodies than by modelling them according to self-moving things from within their horizon of experience, i.e. living things (especially human beings). The universe thus came to be viewed as an eternal, and therefore divine living being, populated by smaller living beings, some eternal (the heavenly bodies; the "spirits"), some mortal or partially mortal (human beings, animals, plants; cf. Venter, 1996:1-5)

It was only after the advent of apparently lifeless automata that Western man could conceive of the dynamics of the universe in terms of a different metaphor: that of an automaton, with a creator god as its engineer and maintenance mechanic (Venter, 1992a:190-198; cf. also Hooykaas, 1972:61 ff; Dijksterhuis, 1950).

From a physical point of view the pictures have been functioning as models, in the sense that they are explanatory metaphorical standardisations (cf. Santema, 1978:2-26) which serve as frames of reference for the understanding of the physical interrelationships in the universe at large. Both pictures, however, have also been functioning as suggestive metaphors, life maps and compasses, which guide individual and social praxis. They have, therefore, in fact become life-andworld views, which determine norms, values, and the structuring of social relationships, as Santema also noticed (1978:7ff). One could even say that from a scholarly point of view, they provided (seemingly) successful ways of explanation, prediction and the determination of regularities with implicit world views, and therefore show the characteristics of what Kuhn called a "paradigm", and some of those he later included under "disciplinary matrix" (Kuhn, 1975: 174fi).

It is not always easy to determine whether, for any specific adherent, the specific picture adopted functioned as only a metaphor through which the world is made intelligible and meaningful, or whether the world is supposed to be a real living organism or a real machine. There may (proportionally) be more mechanistic 
thinkers who believed their descriptions of the world ("machine", "mechanism," "equilibrium") to be only metaphors, while (proportionally) more organistic thinkers may have believed their metaphors ("organism", "organ", "alive", "growing") to be factual descriptions (i.e. that the world is "really" a living being). For my argument it does not matter much whether the adherent thinks the world to be "really" a machine/organism, or only "similar to" an organism/ machine. Once a picture functions as a life-and-world view, it provides a kind of "deeper understanding" of the world, a meaning content to our behaviour (whether contemplative or active), an "ought", which induces us to relate to the world as if it really "is" a machine or an organism. Thus the picture itself becomes an ultimate reality; a design which is (or pretends to be) simultaneously a structuring of reality.

The two world pictures consciously or unconsciously amount to a designing of reality in toto, and therefore to a confusion of picture (metaphor, subjective construct), with reality, in the sense that they function as hermeneutic-heuristic outlines for the (re-)construction of reality. Heidegger (1938:82-83) saw this (although limiting his critique to the subjective rationalism of Modernity), when he stated:

Where the world becomes picture, that-which-is in its totality is determined as the intended-by-man, which he therefore accordingly wants to bring before himself, and have in front of him, and set before him. World picture (Weltbild), essentially understood, therefore does not mean a picture of the world, but the world understood as picture. That-which-is in its totality is understood in this context such that it is just and only that-which-is in as far as it has been set by the representing, re-establishing human beings. When we arrive at a world picture, an essential decision about that-which-is in its totality is executed. The being of that-which-is is sought and found in its being-represented (my translation - JJV; cf. also Venter, 1995:179-190).

Keeping Heidegger in mind, the questioning of the world pictures could be done on two counts: firstly on their being constructs of total reality (i.e. their "Archimedean point"-pretence) and secondly on their nornative (world-viewish) social implications. I shall focus on the second, thereby tackling the metaphor from the angle of its constructed reality.

The weakness and strengths of each of the two dominant world pictures, as social models or standards of explanation (disciplinary matrices) and behaviour (lifeviews), I hope to open up in the next few pages. I shall take issue with the way in which these world pictures, transformed into or functioning as world views, construct (social) reality in their own terms, and the ways in which both of them determine intellectual leadership's thinking, and function as directive forces which cause pain and suffering. Given the fact that such world pictures vacillate in their roles from analogies (pictorial descriptions), and standards (models) of 
reality, to determinants of thought (paradigms or disciplinary matrices) (cf. Santema, 1978:1-26; Botha, 1986:374-383; 1992:78-115) my use of terms will move among these possibilities, as suits the context. My focus will be on the social philosophies suggested by and constructed on the basis of these world pictures; a theory of metaphors, models, and/or paradigms is not intended in this essay.

\section{Organism as societal structure}

The organistic world picture suggests a holistic view of the internal relationships between entities: i.e. it tends to view individuals as parts of a larger whole, on which they are fully dependent for their life and well-being, in the same way that an organ or a member is dependent upon the living body of which it is a part - it cannot be taken out, swopped, or replaced at will. This suggests, therefore, that the individual is part of smaller social structures, which in turn are parts of larger ones, and that the larger ones (usually "states"), have rightful domination over the smaller ones. It may even suggest that an elite leadership with some special (occult) relationship to the whole, rightfully occupies the political power positions. (In such views political and religious power structures will tend to support one another.)

On this hypothesis, the conception of the material universe as a living being in Plato's Timaeus may provide some explanation of his totalitarian views in the Republic. Not only does he view the individual in a certain sense as a smaller replica of the state, but he proposes totalitarian control over religion (poetry), family life, expression, and social status by a quasi-occult communist elite. He tends to view social formations of a non-state nature (such as economic production units, religious institutions, family life, the arts), as simply parts of the political whole, to be subjected to the normative insights of an intellectual elite a view which is still reflected in modern "neo-platonist", organistic, political philosophies like Fichte's.

\section{- Hobbes - the state as a civil person}

Hobbes provides one of the most interesting organistic approaches to questions of social structure - interesting because of its inconsistency, and its explicit treatment of the relationship between "smaller" social institutions and the state as one of "part" versus "whole". Inconsistently with his mechanistic explanation of the state of nature, Hobbes (1972a:170) analyses civil society using the organistic key metaphors of the "general will" and "civil person":

Now union thus made is called ... a civil person. For when there is one will of all men, it is to be esteemed for one person; and by the word one, it is to be known and distinguished from all particular men, as having its own rights and properties. Insomuch as neither any one citizen, nor all of them 
together ... is to be accounted the city. A city therefore ... is one person, whose will by the compact of many men, is to be received for the will of them all; so as he may use all the power and faculties of each particular person to the maintenance of peace, and for common defence.

The change of metaphors (projected as a change from theory to practice) is not innocent. Hobbes wrote the The Citizen earlier than was planned in order to influence the debate on "the rights of dominion and the obedience due from subjects", and to encourage citizens not to disturb the peace of that institution aimed at their preservation (Hobbes, 1972a:103). He summarily rejected, as partial views of interest groups, the criticism that he had allocated too much power to civil authorities, taken away liberty of conscience, and set princes above the law (Hobbes, 1972a:105). He proves keen to show that the dictates of right reason, as expressed in the law of the land, actually express the law of God, and are therefore in harmony with Christianity, thus neutralising the possibility that Christians may be more obedient to God than to their government.

The metaphor is elaborated: the supreme power is like the soul, where the will has its seat, while the council is like the head (Hobbes, 1972a:188). Totalitarian consequences are drawn from it: other civil persons, like merchant companies, are subject to the will of the city, which is supreme; the laws of the land provide the correct interpretation of rational religion. The supreme power is above the law, absolute, and cannot be dissolved by those who compact it into being. To it belongs the sword of justice, as well as of war, the legislative power, the judicature, the naming of magistrates, and the censure of doctrine (Hobbes, 1972a:173). Whatever Hobbes's motives may have been: the basic metaphor of the state as a single living person, is used as foundational "argument" for an allencompassing and overriding state power.

\section{- Rousseau: The absolute will of the totalitarian state}

In his Discourse on Political Economy, Jean-Jacques Rousseau used a wide repertoire of metaphors from the organistic world picture in his analysis of government, with the same result as Hobbes. The (living machine) body politic has the sovereign as "head", laws and customs as "brain", commerce, industry and agriculture as "mouth" and "stomach", public income as "blood", economy as "heart" and citizens as "body" and "members". But it is also a moral being, possessed of a (general) will, which is the source of laws constituting justice (cf Rousseau, 1916a:252-254)

Rousseau anticipates Mussolini's doctrine that the state makes the people; in fact, virtue is nothing more than the conformity of all particular wills to the general will (Rousseau, 1916a:259-260). In virtuous people the heroic passion of patriotism has been made subservient to public reason, and the citizens have become accustomed to viewing their "individuality only in its relation to the body 
of the state ... and to be aware of their own existence merely as part of the state" (Rousseau, 1916a:268). The state as permanent entity has the right to usurp the educational rights of the transitory institution, the family (Rousseau, 1916a:269), as well as to intervene in the economy, with the aim to either maintain or change property distribution (Rousseau, 1916a:272-273).

These totalitarian government powers are founded in a totalitarian view of the sovereign and the constitution, as described in the Social Contract. Morality is founded in law, which implies that the state has the right to uphold morality by censorship preventing the corruption of public opinion (Rousseau, 1916b, IV, vii). Rousseau wanted a (Machiavellian) civil religion based on the model of ancient pagan state religions (continued adherence enforced by the threat of capital punishment), and rejected any claim of Christianity to fulfil this role, supposing it to be a spiritual slave morale which would leave the state without defence and divide the loyalty of the citizen between the priest and the sovereign (Rousseau, 1916b, IV, viii). These totalitarian practices are directly related to Rousseau's basic organistic picture of the state as Hobbesian persona ficta:

\begin{abstract}
'Each of us puts his person and all his power in common under the supreme direction of the general will, and, in our corporate capacity, we receive each member as an invisible part of the whole.' At once, in place of the individual personality of each contracting party, this act of association creates a moral and collective body, composed of as many members as the assembly contains votes, and receiving from this act its unity, its common identity, its life and its will (Rousseau, 1916b:15).
\end{abstract}

Since the Enlightenment, firstly, reality became focused in man (man as the telos of the universe, according to Kant) and reality and history became one. A living universe in this case is a homo-centric universe. Secondly, since ancient times, the organistic world picture showed a tendency towards pantheism (even in quasitheistic philosophical systems like Neo-Platonism). This was associated with magic: everything being alive usually meant everything being "spiritual" and "divine" or "demonic" to some degree. Gradations of spirituality implied a hierarchy, which, on a social level, leads to elitism, whether of a religious (esoteric), political (aristocratic) or gender (chauvinistic) nature. This whole cluster of ideas around the organistic picture can serve to (at least partially) explain the defence of totalitarian and authoritarian regimes in the twentieth century.

\title{
- Organistic holism in Fascism and Nazism
}

Mussolini (1935:7-8), interpreting Bergson's organistic approach, stressed that the conception of the state as a philosophy of life is directly associated with an organic conception of the world. The state is "divine", spiritual, transcends space and time, is universal, national, permanent and moral. The materially physical is 
individual, transitory, subject to natural law, ego-centric, short-lived. Life finds its true expression only in the state, which is conscience, consciousness and general will together - it creates the nation (Mussolini, 1935:9-12). Thus the fascist state assumes full control of the heart of the citizen:

Fascism, in short, is not a law-giver and a founder of institutions, but an educator and a promoter of spiritual life. It aims at refashioning not only the forms of life but their content - man, his character, and his faith. To achieve this purpose it enforces discipline and uses authority, entering into the soul and ruling with undisputed sway (Mussolini, 1935:14).

D.H. Lawrence shares both the world picture and its widest consequences with Mussolini. Mysticism, occultism, elitism, racism, ethnicism are all expressions of his organistic pantheism in the novel, The Plumed Serpent. Aristocratic man, rooted in the living motherly earth and the fatherly, invisible, black sun behind the yellow sun, is here projected as divine ruler of his fellow human beings - he combines spiritualist mysticism with a "blood-and-soil" ideology (cf. further Venter, 1996:17ff). Attention may also be drawn to the theosophic origins of German Nazism - showing the same basic tendencies - for example in the thought of Lanz (who is supposed to have influenced Hitler; cf. Tresmontant, 1991:68 ff). The broad outlines of these ideologies are summarised as follows by Sternhell (note the organistic base)

The essential element here is the linking of the human soul with its natural surroundings, with the 'essence' of nature, that the real and important truths are to be found beneath surface appearances. According to many Volkisch theorists, the nature of the soul of the Volk is deternined by the nature of the landscape. Thus, the Jews, being a desert people, are regarded as shallow and dry people, devoid of profundity and totally lacking in creativity ... The self-same themes are to be met in the nationalist ideology of France: the Frenchman, nurtured by his soil and his dead, cannot escape the destiny shaped for him by past generations, by the landscapes of his childhood, the blood of his forebears. The nation is a living organism, and nationalism is therefore an ethic, comprising all the criteria of behaviour which the common interest calls for, and on which the will of the individual has no bearing. The duty of the individual and of society is to find out what this ethic may be, yet only those can succeed who have a share in the 'national consciousness' ... (Sternhell, 1979:337-338; italics mine - JJV).

Heidegger's sympathies with Nazism was probably also based on a shared world picture. In his attempt to develop a pre-Christian philosophy, he embarked on a "neo-platonist" search for the primitive ground of being, which finds expression in authentic existence. This search excluded the idea of a transcendent creator god from his seminarian days (cf. Tresmontant, 1991:460 ff). Thus all being can be conceived of as saturated with the "divine" ground, which may be subject to 
Mechanistic individualism versus organistic rotalitarianism

forgetfulness, and therefore imposes the calling to search for it while "remaining" where you "are". In his later works he identifies "essence" or "identity", expressed in language, as this "ground"-language being the archaic word which unifies the world quaternity: heaven versus earth and divine versus mortal. The physical aspect (sound, mouth, body) of the expression of the archaic word through man, is not conceived of in terms of the meaning-sound-dualism, but is considered as essential component of language, through which we are bound to region and earth:

In the tongue (dialect) every different landscape and therefore the earth speaks. The mouth is not simply a kind of organ in the body represented as organism, but body and mouth belong in the stream and growth of the earth, in which we, the mortals, flourish, from which we receive the thoroughness of a rootedness in soil. Together with the earth we also certainly loose the rootedness in soil (Heidegger, 1959:205; my translation and italics - JJV)

South African Afrikaner leaders, such as H.F. Verwoerd (murdered prime minister and "architect" of apartheid), N. Diederichs (former minister of finance and state president), P.J. Meyer (who headed the S.A. Broadcasting Corporation), and some others who became influential professors in the social sciences in Afrikaans universities, studied in Germany in the Weimar era, where they imbibed the organistic pantheism of German nationalism (philosophically rooted in Fichte, Herder, Schelling and even Boehme), and developed social theories in which the ethnic nation ("volk") is exalted as the organic unit through which institutions and individuals become human and receive their meaning (Morphew, 1989:63-80). The dispensation which they had in mind for South Africa followed this basic tenet to its ultimate consequences: every ethnic nation had to have its own piece of land, governed by its own people and its own institutions, which could only thrive within the ambit of such nationhood. This was the basis for the establishment of ethnic universities, schools, the prevention of mixed marriages, the homelands, et cetera. "Volk" and state more or less coincided, and totalitarian "volk" became totalitarian state.

\section{- Thematic similarities among the twentieth century authors}

Twentieth century authors tend to relate human beings to one another in terms of organically conceived social institutions such as the "nation", the "state", et cetera. In this respect they do continue the basic approaches of Hobbes's and Rousseau's organistic metaphorising of the social scene, and the totalitarian consequences are undeniable. Twentieth century authors, however, go further, or rather, tend to revive ancient mythological modes of thought: the rootedness in a motherly earth, the blood-and-spiritual bond with the forebears, the elitism based in the "occult" capabilities of the aristocracy, are all reminiscent, not only of 
Greek organistic thinking, but also of pre-Hellenic Egyptian and Babylonian "political" theogonies.

\section{Individuals as machine parts}

The mechanistic world picture initially served to explain the dynamics of the physical universe on the basis of a cultural product, the automaton. Very soon, however, the picture was transferred to other areas: first, to explain physiological processes, and later also social processes (cf. Venter, 1992a:191-198).

- The automaton: independence of the part from the whole

The mechanistic world picture significantly differs from the organistic one in its suggestions with regard to the part-whole-relationship: the parts of a machine can (with relative ease) be removed, repaired, replaced, or used as spare parts for other machines. It thus suggests a relative independence of the part from the whole (compared to an organ or member in the organistic picture), and an aggregational view of the whole, especially when it concerns social institutions. God can be ("Christianly") viewed as both engineer and mechanic, or (deistically) as only the engineer (leaving the "automaton" to its own autonomous contrivances).

\section{- The newtonian metaphor of gravitational equilibrium}

After the initial metaphor, that of the clock had (in discussions of social problematic) been replaced by the newtonian one of gravitational equilibrium, a process-feature could be introduced into the picture: "machines" could now be seen as aggregations of equilibrating (and disequilibrating) forces. This disclosed important possibilities for the historicising of reality and the body politic in the eighteenth century: one could resist the idea of the nanny-state, assuming autonomous individual citizens, each taking care of his own interest, while the aggregation still functions according to strict natural laws of progress by virtue of equilibrating competition.

- Hobbes: A mechanistic dissolving of the whole into its generative parts the watch metaphor

Hobbes (1588-1679) was too early to profit from a metaphorising of Newton's (1642-1727) theory of gravitation (published 1687) for his mechanistic explanation of the state of nature. In spite of his organistic picture of the civil state, his conclusions about the state of nature are the results of an analysis of the civil state as an existing whole, viewed as a "watch or some such small engine" to be taken apart (and not of an empirical study of the natural conditions; cf. Hobbes, 1972a:99). This discrepancy can probably be explained by his motive of instilling obedience in rebellious citizens by providing scientifically indisputable arguments proving (a priori, of. Venier, 1994:37-41) the horrors of living in a 
Mechamistic individualism versus organistic totalitarianism

state of nature in comparison to the security provided by the civil state (cf. Hobbes, 1972b:41-42).

This mechanistic (metaphorical) dissolving of the whole into its generative constituent parts, produces a picture of the state of nature in which individuals (equal in right to everything), following their (conflicting) appetites (rather than reason), as well as striving for self-preservation, are in constant competition or conflict with one another. But these premises also necessarily imply that such individuals will move into a civil state by contract aimed at self-preservation through the formation of alliances (Hobbes, 1972a:115-118). The compact being made, a living being, the body politic, comes into being, and all the totalitarian consequences sketched above become operative. The alternative, therefore, is: either bellum omnium contra omnes, or a totalitarian and authoritarian security state. The first disjunct is supposed to eliminate itself, but can reappear if citizens become disobedient.

Bernard Mandeville transformed civil society itself into the Hobbesian state of nature, suggesting that society flourishes as a result of egoism (including crime), and that intervention, even in the form of charitable schooling of children, would be detrimental to its well-being.

- Adam Smith: the equilibrium metaphor and the human mind, moral life and economic processes - the market metaphor

It was probably Adam Smith who first saw the applicability of the equilibrium metaphor to the human mind (1980), moral life (1976), and economic processes (1950). Both Adam Smith and Immanuel Kant shuttle between the organistic and the mechanistic world pictures. They cannot afford to finally let go of the former: they share the Enlightenment faith in progress, and therefore presuppose a homocentric teleology of nature, working in and through man, and using as its instrument the supposedly mechanical process of competition amongst individuals and groups. This aspect becomes the dominant one, for "God's" teleology can only be approached through the analysis of human efficient causality - taken here in a fairly literal mechanical sense.

Smith views all social relationships in terms of the market as model or standard. This presupposes that the individual human being naturally relates to others in a contractual (bartering) way:

Society may subsist among men, as among different merchants, from a sense of its utility, without any mutual love and affection; and though no man in it be bound in gratitude to any other, it may still be upheld by a mercenary exchange of good offices according to an agreed valuation (Smith, 1976:86). 
But such an utility-based social order is "futuristic" in Smith's view, since utility is only recognised by a mature, rational humanity. For the time being mankind is still in the emulation phase, in which the passion for out-shining others is dominant (Smith, 1976:16, 41ff, 114ff, 145ff). But even in the passionate emulation phase, progress is served by self-interest, "intuited" by the (hedonistically conceived) sense of agreeability or disagreeableness. In the face of Hutcheson's rejection and Mandeville's cynical acceptance of self-interest, Smith elevates it to the motor of welfare, at a level midrange between the social and the unsocial passions. Self-interest is moderated by the judgment of the impartial spectator - a proto-freudian internal, supposedly objective super-ego, which executes judgement under the guidance of agreeability, according to the rules of prudence (longterm self-interest) and justice (social interest). In this way Smith hopes to avoid conventionalism (accepting that the individual becomes a moral creature only through society), as well as arbitrary, individualistic sentimentalism (Smith, 1976:130-150).

In the context of economics, Smith determines the basis of self-interest by the Enlightenment historiographical method of retrospective extrapolation (based on the law of progress) - extrapolating to what man "originally" (or "naturally") is: a farming barterer who owns the full product of his labour. The amount of labour time invested in a product will therefore form the basis of bartering negotiations; historical developments add the rent price of land and the profits of stock to this base (Smith, 1976:49-50). Individuals therefore (in an "original" sense) take care of their own interests in terms of the value of their labour, and this provides the equilibrating forces which will move the market price in the direction of the "natural" (equilibrium) price:

The natural price, therefore, is, as it were, the central price, to which the prices of commodities are continually gravitating. Different accidents may sometimes keep them suspended a good deal above it, and sometimes force them down even somewhat below it. But whatever may be the obstacles which hinder them from settling in this centre of repose and continuance, they are constantly tending towards it (Smith, 1950:60; my italics - JJV).

Smith is as much a contractualist as Hobbes and Rousseau; yet his view of society as a totality differs radically from theirs: the market metaphor - for him probably more than a metaphor - implies that society is a process of continuously contracting individuals; the state is relegated to the status of a protective framework for this process.

- Kant: history is subject to mechanical, causal laws - the automaton

Kant (1975a) uses metaphors reminiscent of those of Adam Smith in his analysis of historical social formations under the guidance of the teleology of nature. Using the same retrospective extrapolation method, he uncovers the development 
of reason as freedom in the individual (cf. also Venter, 1992b:33-38), which practically means a quasi-Hobbesian natural state of unsociability (Kant, 1975b:38-40). Conflict and competition are, as in Hobbes, the forces which necessitate the establishment of communities, and, in the end, of a world community or league of nations in which rationality and eternal peace would reign. Kant's view of social history is an explicit formulation of the doctrine of the balance of power, starting with autonomous individuals, through smaller communities and national states, to end up with the league of nations:

\begin{abstract}
All wars are, therefore, so many attempts (truly not in the intentions of the people but in those of nature), to establish new relationships among states ... until in the end, in part by the structuring of the best possible legal order, in part by communal external agreement and legislation, a situation is established which maintains itself analogously to civil society, just like an automaton. The barbarous freedom of the already established states ... necessitates that our species find, in addition to the in itself salutary resistance of many states, a law of equilibrium ... (Kant, 1975b:44).
\end{abstract}

"Automaton" here takes the function of a model (a pictorial standard); but then a strongly representative model, intended to express a (for Kant) undeniable reality: history is subject to mechanical, causal laws.

The views regarding society of Malthus, Ricardo, and Darwin follow the same metaphorical pattern, based on the same mechanistic picture of the world (cf. Venter, 1994:5-16), stressing the "autonomy" of the "parts" - individuals or smaller groups, which, through competitive activities, act as motor forces of history.

\title{
- Darwin's metaphor of natural selection
}

Darwin transferred the competition-equilibrium matrix, implied in the metaphor of "natural selection" (and he explicitly acknowledges it to be a metaphor), to the study of nature (in The Origin of Species [1968] cf. Young, 1988; Venter, 1996: $13 \mathrm{ff})$. He also used this metaphor in a normative sense, as a policy proposal regarding human population development, opposing family planning schemes, so as to ensure the continued progress of mankind through the competition of individuals. For the moral and legal sphere, however, he moderated the demands of health and vigour in the individual (vis-a-vis social well-being), by presupposing another equilibrating process: that between altruistic and egocentric instincts (cf. Darwin, 1906:194, 945-946). He thus avoids the "social Darwinist" consequence of summarily characterizing the competitively successful as the "civilized", "hard-working", or "morally good" (as was done by Sumner, 1934, and others.) 
One should not summarily conclude that all of these thinkers were in fact insensitive to the "immoral" and/or "sociopath" implications of the egocentric individualism they were preaching. They rather trusted the automatism of the equilibrium process to take care of the interests of "justice", "sobriety", "honesty" on the basis of real "merit".

\section{- The market metaphor as the basic metaphor for the social sciences}

Equilibrium theorists, such as the New Classical and the Monetarist economists of the past few decades, seem to put their trust exactly in this same automatic fairness and warranted morality of the "market" mechanism - on condition that we, like Adam Smith - accept the market metaphor as the basic explanatory or predictive metaphor for the social sciences.

To keep the competition-equilibrium structure workable as a standard approach (disciplinary matrix) which is supposed to provide economists with predictive laws, some very "unrealistic" assumptions had to be made, such as the availability of perfect infornation (on costs, tastes, alternatives, for both producers and consumers), perfect competition, a perfect market. As irrationalism grew and the organistic picture regained some foothold, these assumptions have been challenged in different ways. In Keynesian economics uncertainty plays a pivotal role, and therefore the expectation of equilibrium becomes problematic (although Keynes still attempts to use it; cf. Keynes, 1936; Torr, 1988:39-50). And according to Von Hayek the assumptions express no more than the a priori possibilities open to an individual in the market; it provides no analysis of real competition processes, which are clouded by uncertainty, and at most, tend to co-ordinate the economic and social actions of individuals. Von Hayek, however, retains the market metaphor for all of society in terms of a "methodological" (not: ontological) individualism, according to which the market functions as a hermeneutical process (cf. Von Hayek, 1949:3354; 93 ff; Venter, 1996:27ff).

\section{- Monetarism}

These innovations have not totally eliminated the competition-equilibrium matrix from the realm of economics. In New Classical economics and in Monetarism (both high profile schools which have influenced policy making very strongly), it still holds sway. There are claims that are also applicable in - and in fact the best approach for - other social disciplines.

In Friedman's version of Monetarism, general equilibrium analysis is partitioned into different analyses of specific problems, while the New Classicals tend to believe that everything depends on everything, and that therefore the partitioning of problems is invalid. They share, however, the basic tenets that economic agents are, to the limits of their information, consistent and successful optimizers 
(that they make most of their opportunities and are therefore in equilibrium); and that agents hold rational expectations (i.e. they make no systematic errors in evaluating the economic environment; Hoover, 1988:182-193). These tenets express the classical competition-equilibrium matrix in an irrationalist context: individuals act optimally for their own benefit, and what they do expect is what they should expect. In the New Classical school the automatism is so strong that institutional analysis of even the business enterprise itself is rejected in favour of treating it as a blackbox causal link between the actions of individuals and price changes (Machlup, 1967:9).

Importantly, in the Monetarist case, the validity of these tenets is not limited to economics. The Monetarist, Karl Brunner, explicitly rejects a multidisciplinary approach to economic problems (including, as he calls it, the Keynesian "sociological perceptions of non-market situations"), and wants to apply the basic principles of Monetarism to other social disciplines, as if economics provides the only valid social scientific approach (Klamer, 1985:183):

We reject, on the other hand, an escape into sociology which offers no relevant analytic framework. We maintain that socio-political institutions are the proper subject of economic analysis. This entails an entirely different view of the political institutions and their operation. The sociological view typically supports a goodwill theory of government and yields conclusions favouring a large and essentially unlimited government. An application of economic analysis, in contrast, alerts us to the fact that politicians and bureaucrats are entrepreneurs in the political market. They pursue their own interests and try to find optimal strategies attending to their interests. And what is optimal for them is hardly ever optimal for 'public interest' (Brunner in: Klamer, 1985:186).

\section{- Friedman: Political markets versus economic markets}

Friedman provides us with a simple exemplary analysis of political markets versus economic markets, in an attempt to show that the political market is actually a less efficient system of coordinating individual self-interest, which will take away our individual freedoms, the more we put our trust in it. According to him the accepted distinction between the economic market as aimed at selfinterest and the political system as directed at public interest, is a myth - the latter actually only serves the self-interest of the public servant (to be human, is to pursue self-interest). Secondly, exchange in the political market does not take place on the basis of "one man one vote", for it actually functions on the basis of weighted votes of small interest groups, which determine a whole package to be voted for on a "yes/no" basis, whereas the economic market provides for a much freer and more equitable proportional voting system ("one man one dollar"), in which you get what you vote for (voting for every item separately). The essence 
of a political arrangement is coercion; that of a market arrangement is voluntary co-operation between people (cf. Friedman, 1976:6 ff).

Friedman (1976:11 ff) views the equilibrating forces as moving parallel to another: if government spending increases on the insistence of the electorate, without taxes increasing too (i.e. money is created ahead of production), then this is balanced by a hidden tax increase called inflation. Increased government spending is also accompanied by increased government controls and security provisions of all kinds, which is balanced by decreasing efficiency and freedom and increasing collectivism (Friedman, 1976). Friedman is prepared to invert this causal chain: any increase of private, free enterprise, capitalism is accompanied by an increase in political freedom - in fact, individualistic free enterprise capitalism is a sine qua non for a free political system. Even social welfare in its broadest sense ("elcemosynary activity" - the establishment of non-profit institutions like universities, libraries, hospitals, et cetera) flourish during periods of decreasing government controls and increasing free enterprise, Friedman jubilates, on the basis of what he sees as the results of 19th century laissez-faire policies (Friedman, 1976:25 ff). Although Friedman seems to provide us with a strictly "positive" (rather than a "normative") analysis of the economic-social reality, his analysis is clearly aimed at promoting "freedom", and is therefore normative in spite of its pretences.

These parallels show the grip which mechanistic thinking has on Friedman. Von Hayek (1949:30), as anti-collectivistic as Friedman can ever be, but rejecting such a purely mechanistic approach, could not find an automatic correlation between individual freedom and social equity; in fact, he accepts a trade-off between the two as unavoidable (cf. also Venter, 1996:39).

Initially, the mechanistic picture functioned as a methodological directive, by which the handling of the "organs" of Hobbes's social organism was legitimized, just as if they were "independent" machine parts. This approach gave a kind of "autonomy" and mutual antagonism to the "parts", which was individualistic, at least in consequence. Gravitation theory disclosed the possibility of a processlike approach within the mechanistic picture, by which historical progress (including the automatic establishment of justice and morality) could be modelled, on the supposition of individuals in competition, given disequilibrating forces to prevent stagnation. In spite of the collapse of the faith in progress, and in spite of criticism of equilibrium theories, the disciplinary matrix of self-interested individuals who create economic welfare as well as social welfare (and justice) through an equilibrating "market mechanism", remains very strong indeed. In this tradition scant attention is given to the structures and functions of different social institutions such as the business enterprise, the state, the family - its analytical 
toolshed makes do with terms like "individual", "competition", "self-interest", "market", "buy/sell", "equilibrium".

Ironically, the deterministic general equilibrium approaches have been criticized for eliminating real competitiveness from their theory. As the representations of the competition-equilibrium matrix became more overtly mechanistic (especially as a consequence of the "perfect"-assumptions), its power to explain or describe the economic and/or social processes, qua processes, decreased. Under such theoretical ideal conditions as represented under the "perfect"-assumptions, the balance of powers is immediate or permanent (or, more technically, takes place in mathematical time rather than Bergsonian durée), while in reality, "to compete" involves surprise, novelty, innovation, and even dissembling over time (cf. Addleson, 1988:462-463).

\section{- Principle of competitiveness well established in Western culture}

It is, however, noteworthy that the principle of competitiveness has been well established in Westem culture, also in the analysis of social processes. Competitive individualism has been transferred to competitive nationalism, and it seems as if competition is no more simply a means, as in the eighteenth century, but rather something like a norm or an end. The "winning nations" are to be taken as norm by the "losers" in the Third World; the GATT agreement opens up "free trade" all over the world; "competitiveness" is the supposed answer for a country's industries; at school, winning, whether in sports or in intellectual pursuits, counts, and coming second almost does not; "publish or perish" in the academic world is only an expression of the competition motive as norm and does not necessary road to "quality" or "excellence".

It is not all that rosy however: countries are flooding each other's markets with more or less the same products; Third World countries are forced to compete on an unequal footing with First World countries, and become more and more indebted to them; the accentuation of individual and particular interests tends to strengthen selfishness, and can be detrimental to creativity; human lives are losing their value as self-interest in the context of a collapse of values turns into outright egoism.

\section{Perspective: Is there a way out?}

The organistic world picture promotes a "whole" versus "part" approach in the analysis of social structures and processes. The interests of the "whole" take precedence over those of the "parts", i.e. organistic thinking implies "holism". It is not clear which criteria are used to identify important "wholes" (usually states, tribes, or ethnic groups or even "society") - it seems as if cultural, racial, power, and geographical considerations are taken into account without much critical 
investigation. Whatever differences there may be between "parts" and their "whole" are easily forgotten as smaller institutions are usurped by the interests of larger or stronger ones. The consequences are not only almost complete control over the lives of individuals, but also of associations which differ in their primary aims (or functions) from the primary aims (or functions) of the "whole". This is totalitarianism. It can be of a "majoritarian" orientation (like that of Rousseau), or more authoritarian, as in Fascist or Nazi elitism - neither has any patience with religious, educational, artistic, sports, or other institutions viewing their roles as different from the aim of the "whole".

The mechanistic picture rejects dominance by a supposed social "whole". Mechanists tend to view the encompassing, powerful institutions as aggregations of individuals - a suggestion inherent in the relative independence of a machine part from its machine whole. This view made it possible to combine individual autonomy with a deterministic view of historical progress, in which justice, peace and moral decency could all be seen as the equilibrium product of the opposing "gravitational" forces of self-interest. This world picture allows for much patience with the role difference of sinaller and less powerful associational forms, and wishes to reduce the powers and functions of the strongest one, the state. It assumes, however, a market totalitarianism, and trusts the "market" (i.e. the competition-equilibrium matrix) to solve the problems of justice, morality, peace, and social welfare. Efficiently successful "trading" is supposed to (always) leave the barterers better off than before! This trust discloses the capitalist values hidden behind the mechanistic metaphors and analytical patterns. Although economistic in its orientation, its analytical approach obstructs any sense of institutional differentation. It is therefore unable to get a clear picture of the ethical role of the family, or the primarily justitial aims of the state, vis-a-vis the profit aims of the business enterprise. Thus all other institutions become progressively disempowered with regard to self-interest as such, and egoism becomes the norm.

\section{- Can any liberating mediation between the two world views be effected ?}

It can indeed be asked whether there is a way out of this inpasse; whether mediation between the two world views can be effected. Another issue is whether these world views possibly include some valuable elements which could direct us in a direction away from both of them?

The organistic picture seems to recognise the different functions of different social institutions, but sublimates these into the aims and interests of the whole. The adherents of the mechanistic picture try to avoid the totalitarianism and authoritarianism which we have found associated with the organistic approach, and allow for much more freedom of the individual members of "society" (and as a result of this, for the freedom of weaker institutions). Yet the latter is no more 
able than the organists to clearly outline the pluriformity of social relationships, and allow for the freedom of their functioning as social unities, for it represents "society" as a number of configurations of forces (where self-interest is the real motor force), neglecting the question of "power" inequalities behind the forces, as well as the differences in social context in which these "forces" operate.

\section{- Pictures as norms: integrationism versus isolationism}

Furthermore, once any (single) picture is used to explain all of reality and to give meaning to life (i.e. when a world picture is transformed into a world view, regardless of whether it functions for its author in a "real" or in a "metaphorical" sense), it fulfils both a "factual" and "normative" role - in other words it encompasses both an "is" and an "ought". In the present case this means that for both pictures the world (which includes human social life) both is (similar to) an organism or a machine, and ought to be treated as (similar to) an organism or a machine.

Thus the organistic world view is holistic both in a factual and in a normative sense. It contends that individuals and smaller institutions are (similar to) the organs of an organic whole, and that it is wrong or evil for us human beings not to live up to our "part"-playing as "organs" of the "organism". It cannot but react negatively (crying "sedition", "treason", "disloyalty") in response to any claims that a smaller/weaker social institution (say a school), might opt to follow aims differing from those of "society" (which, nowadays, is equated with the state, or the "nation"). Especially nationalist political authorities are unreasonable in their demands that all institutions fall in line with "national" aims. Churches, sporting bodies, academic associations, need not, however, for example, limit their spheres of influence to national boundaries. In terms of its normative implications, the organistic world view tends to (enforced) integrationism.

Equally, the mechanistic world view zigzags between "is" and "ought". The representation of the world as (similar to) a machine/automat incorporates a characteristic of modern technology: the abstraction from a specific solution of a specific problem by using "neutral" modular components which (though limited by the purpose of the particular machine), still have "a certain artificial independence" (Schuurman, 1980:15). Thus society is represented as consisting factually of an aggregate of (self-interested) forces; this is dialectically switched into promoting self-interest as the basic norm for all social functioning. In contrast (and sometimes clearly in reaction) to organistic holism, it takes an isolationist stance, promoting a "private sector", individualistic approach with a strong economistic slant to it. There is some recognition of the right to freedom of non-state institutions, but no thoroughgoing analysis of their different institutional functions seems to emerge after the fragmentation of "society" into neutral machine components. 
Von Hayek recognized something valuable in both pictures. He carefully and qualifiedly borrowed metaphors from the organistic approach, given its sensitivity for structural unity. But he also appreciated the openness for freedom and the anticollectivism of the mechanistic approach, and held onto this in the form of a so-called "methodological individualism" (Venter, 1996:236).

\section{- Institutional plurality}

To avoid imitating Von Hayek's awkward ride on two horses parting ways, we should first enquire whether the two world pictures really cover the whole field of experience, as they pretend to, and whether they really (in "principle") form alternatives to be expressed in an exclusive disjunction. This difficulty is probably rooled in the fact that the two pictures have become world views - their limitations as only metaphors have been forgotten, and they acquired authority beyond their legitimate applicability.

One can, of course, model many aspects of "reality" in terms of mechanical metaphors (for example) the movement of limbs in a body. The very existence of organic chemistry and biochemistry tells us, however, that such metaphorising must have limitations. In the same way we can use biotic metaphors to express ourselves about non-biotic matters, such as the "growth" of the money supply, yet realizing that the applicability of this metaphor is limited by the fact that human beings make decisions about the increase in the quantity of money (which is clearly not the case with the growth of an organism). Similarly one can also draw metaphors from other fields of experience. Darwin's metaphor of (natural) "selection" (by his own admission) was drawn from human culture (the selection practices of breeders); he had to supplement its lack of a selection agent by metaphorising "competition" into a natural process (an approach ridiculed by Marx as transferring the British economy into nature). Thomas Kuhn (1975) used the metaphor of "conversion" from the area of religion, to describe the social behaviour of the adherents of a "paradigm" (another metaphor probably drawn from grammar).

\section{- One single metaphor cannot explain the interrelationships of all entities}

The plurality of possible metaphors themselves point to something beyond language - the plurality of possible relationships between human beings and whatever is in their environment. Surely the relationship between husband and wife differs from their relationships to their expected baby, and this again differs from that of the family doctor towards the embryo. Society has long ago recognized this difference, and therefore set limitations on the medical involvement of doctors with their own family inembers. And doesn't the relationship of the sculptor toward a piece of marble differ from that of the person who sells it to him? Of course one can attempt to reduce both the latter relationships to their physico-chemical properties, but as Von Hayek has so clearly shown, one 
will then be unable to make any specific sense of these relationships, or of any other cultural activity (Von Hayek, 1952:17ff; Venter, 1996:231ff). Every human entity, from the moment of conception, exists in such a plurality of relationships - the Hobbesian state of nature as a state of isolated individuals was the product of abstractive projection (as recognised by Hobbes himself, but forgotten by Rousseau).

The differences among these relationships disclose the possibility that they may be structured into different institutional forms. A group of people playing football may found a club as an institutional form. The club will need capital assets (such as a playing field); has to establish itself as a "legal person"; will need an administrative executive (chairman, secretary, etc.) as well as a team leadership (captain; vice-captain), and a trainer. A drama reading group, on the other hand, can get along by using a member's living room and kitchen facilities, taking turns to organize meetings, but cannot get along without some intellectually developed minds. A state needs elaborate mechanisms for the protection of its citizens' rights; a school only an organized teaching staff, children who want to learn, and a minimum of administrative and physical infrastructure.

Once a single metaphor is used to explain the functioning and interrelationships of all entities, sensitivity for the differences among social relationships as well as the peculiar forms of institutionalizing which they may assume, is lost. Whether intended as "reality" or as "only metaphor", both the mechanistic and the organistic world views are reductionistic in their representations of social reality a reductionism which has worrying nonmative implications (as I attempted to show above). The social modelling of the two world pictures provide normative models which tend to cover the whole area of social life, in all its forms. The mechanistic one tends to reduce all social forms to that one of which the supposed analogy with a machine was first perceived - inter-individual competition (of which the market remains as the ideal type). The organistic one subjects all social forms to the interests and power of the one perceived to be the most encompassing, and model them according to the relationship of an organism to its organs.

\section{- Swop the roles and see what happens}

The secret, probably, is to find a theoretical way of limiting the expansion of such metaphors. One way of going about this could be a kind of deconstructive behaviour-swopping procedure, in which the institutional hierarchy within the ambit of the metaphor is inverted.

In the ambit of the organistic metaphor the state or the nation (and its aims) tends to have the upper hand; thus we can limit this metaphor by swopping state behaviour with that of a less powerful institution (such as a high school). In the 
ambit of the mechanistic metaphor, the market dominates: we can thus apply the normal behaviour of (say) a married couple to a market situation, and vice versa.

* Imagine organizing a school primarily according to the principles of law and order using a military mode of training, the youngsters carrying arms and doing the drill, organizing themselves into political parties struggling to gain the upper hand; the principal and staff being elected by the children according to the principles of multi-party democracy. Will this provide for a balanced process of enculturation, which schools normally stand for? Need I stretch the imagination to include the possibility of such a school becoming a mini-state in a neighbourhood? (For some South-Africans this may be a nightmarish remunder of recent historical reality.) Imagine establishing a state in conformity with the normal educational principles of a high school, treating all citizens as schoolboys and girls; the head-of-state following the decisionmaking processes, awards and punishments of school principals; the cabinet handling the electorate as so many classrooms full of schoolgoing children.

* Imagine a marital relationship constructed on the basis of Adam Smith's exchange of good offices rather than benevolence:

Hubby: "Honey, like a wine'n dine tonight?" Honey: "O'course, but what d'ye have in mind?" Hubby: "Oh, nothing much ... a quiet little place like Spartacus's Greek Cuisine; they have nice smalls, you know; good food; nice music ..." Honey: "I didn't mean that. I mean what returns do you hope to get from your investment?" Hubby: "Not much this time, you know ..." Honey: "OK! you may touch my knees; but you know I get a headache if you go any higher." Hubby: "Well! If you get that headache tonight, I still have the option of popping in at Clare's. She doesn't get headaches!" Honey: "Do you want me to wear that dress with the thighhigh slit?" Hubby: "Now we're getting somewhere. Competition always produces quality, whether service or product ..." (Do we need to construct an example of a buyer treating a shop assistant in the way spouses relate to one another?)

The examples may be ridiculously trivial, yet they illustrate the point: stretching their social implications to the limits by deconstructive behaviour-swopping, highlights the strange consequences of these reductionist normative metaphors.

\section{- The pain/suffering indicator}

A second, more serious and less trivialising approach to limit the dangerous consequences of misleading "is-ought" metaphors through the bridging of the "isought" gap, can be found in the pain/suffering indicator. The interplay between "is" and "ought" in the two metaphors has already been noted. Accepting that the direct move from "is" to "ought" is invalid, it can still be argued that an indirect movement is possible - via the pain/suffering indicator. 
Briefly: "suffering" implies "pain" (whether we use these words metaphorically or literally); but "pain" does necessarily imply "suffering". "Pain" belongs to life's warning systems: when I touch a hot object, the pain I feel warns me to pull my hand away before serious damage is done, i.e. before an antinomic situation replaces the regular one. (Acceptable punishment would then rather belong to the category of pain than of suffering.) Suffering may be described as the pain caused by a serious and long-term antinomic situation.

Thus, whenever a (supposedly) normative social metaphor is seen to cause pain, we have an indication of an antinomic situation present or approaching. I cannot feel the other's pain, therefore I have to take his/her/their communication of pain seriously as an indicator that the "oughts" which goven my behaviour need adjustment. Undeniably Christ's maxim of doing unto others as you would have them do unto you, opens up a world of possibilities to swop shoes, imagining the consequences in terms of pain and suffering, so as to discover when a situation may be or become antinomic.

How many millions have died because of totalitarian regimes based on an organistic picture of social life? How many may have starved or have been marginalised (and still are), under the assumption that competition will automatically care for justice (not to mention stress and depression as the diseases of our time)?

\section{- Differentation and integration}

Thus, over against the totalitarianistic holism of the organistic world view, I would, in line with the Neo-Calvinistic tradition - for instance A. Kuyper (1880), H. Dooyeweerd (1957), D.H.Th. Vollenhoven (1964), plead for acceptance of the norm of societal differentiation and juxtaposition (usually called "sovereignty in own sphere").

The mechanists are right - social differentiation is normative. But one can only avoid an isolationist (or even disintegrationist) concept of differentation if the principles of differentiation are not located via self-interest, but through a thoroughgoing analysis of the possible forms the different human relationships may assume, determined by all the possibilities of interacting with, or undertakıng responsibilities and tasks in the "world" as environment

Differentiation, in fact, implies an involving self-assertion, and not at all a separation of institutional forms. Societal institutions speak, each in its own way, to mankind. Academics produce intellectual ideas about the world at large in a scholarly way, and in fact need their academic freedom and institutional autonomy for responsible involvement conforming to the demands of scholarly work. No state should be happy when churches, universities, sporting bodies, writers associations, all willingly submit to "national ideals", for this is an 
indication that these institutions do not care about their own tasks anymore, neither do they contribute freely and independently (in their own particular ways) to the well-being of the state as their neighbour

Some sporting bodies love to "separate" sport from politics, and some liberals believe in the separation of church from state. It is clear that they should be independent from one another (authority-wise and regarding their tasks), but this cannot mean "separate" - at least not in the sense that the one cản act as if the other does not exist, or as if the existence of other institutions in its vicinity is not mirrored in its own composition and need not affect its choices. All of the human-in-the-world problematic will (in any case) find expression in each social institution - the issue is only: how to actively take this problematic into account in the functioning of an institution.

The economic situation in a neighbourhood will find expression in the neighbourhood school, not only in the facilities available in the school, but also in the attitude which the school has towards the neighbourhood and to other institutions in it. A school in a poor neighbourhood might search for creative ways of teaching with minimal means, or involve the parents in the physical upkeep of their school instead of asking for more cash; it might focus in its teaching on the transfer of skills which may prepare the children for early entry into the job market; it might even provide adult education programmes to improve parents' chances to find work. But if it wants to keep up the pretence of being a school, it cannot give up teaching children well, and it should resist attempts from other institutions to instrumentalise it for job creation, or to prcach a national ideal (even the ideal to care for the poor). Yet it cannot and should not go about its educational task in isolationist terms. For, in the latter case, the expression of the neighbourhood problematic will wreak havoc in the educational situation itself. (A trivial example which is everyday reality in Africa: children of illiterate parents from a shanty town usually differ in their proficiency as well as their interest in reading, from those that come from middle class neighbourhoods with a neighbourhood library and well-educated parents; and teachers better take note of this situation.)

In more general terms: the norm of integration holds in the latter case. This implies that social institutions should constructively ask themselves: how does the full human problematic of our environment (which may be a Heideggerian "nearness" rather than only a physical neighbourhood) reflect itself within our specific differentiated task and what constructive demands does this make on the execution of our daily task?

Should an institution neglect this norn, it will surely create tensions and suffering in its own membership. One example: the capitalist ethic remunerates winning as an indication of "excellence". For the travelling salesman this may mean being 
Mechanistic individualism verstus organistic totalitarianism

compelled "voluntarily" to remain on the road away from wife and children. It seems to be in his interest to submit voluntarily to the interest of his employer this is an isolationist (even disintegrationist) institutionalized demand, which causes suffering because it is not integration-sensitive. And the insensitivity is not something additional or accidental, but built into the very institutional form, which does not set fair standards of a good day's work, but leaves it to subjective guessing in competitive circumstances. No wonder the pendulum presently seems to swing in the direction of integrationist holism!

\section{Conclusion}

To draw the lines together: Von Hayek has pointed out that totalitarian planners pretend to have an Archimedean point above their historical situation, giving them the encompassing knowledge of society which makes totalitarian planning possible, i. e. they play God to their fellow human beings. Nobody can have such insights and knowledge; therefore Von Hayek prefers to leave social developments to the spontaneous generation and functional adjustment of institutions; the interaction of individuals in reaction to "market" indicators empower them incomparably more than any planner can do (cf. Von Hayek, 1952:91-102). From a religious point of view, Neo-Calvinists will probably applaud Von Hayek's criticism of totalitarianism, but will have to ask whether his idea of the spontaneous adjustment of institutions (likened to the cliange of aims with which a footpath may be used), does not leave them wide open to instrumentalising by power formations other than the state, as is presently becoming practice among the so-called "New Right" (rightwing liberal) political groupings (cf. Vieux, 1994). The convergence of spontaneous institutionalising in different cultures seems to point to a stable range of different possibilities given in creation: playing, producing art forms, adoration, the providing of food and shelter, education of youngsters, caring for faimess, eating and drinking, producing offspring, intellectual thinking, building of power formations. Neo-Calvinists will plead for respect for the own integrity of these institutional possibilities, and will especially plead that power formations legitimise themselves in, and restrict themselves to the institutions in which they occur. The principle of "sovereignty in its own sphere" simply appeals for stability in disclosing the potential of creation, for the recognition of human limitations as creatures coram Deo, and for the recognition that the powerful institutions are not better equipped to handle the affairs of the non-powerful institutions; on the contrary, they will tend to use the less powerful for their own interests. This is what the norm of differentiation actually wants to express. 
Finally:

- The nonn of differentiation and the norm of integration are not in a dialectical tension with one another

- Differentiation simply means that the institution recognises its own specific task in a network of relationships and continuously adjust its institutional form to improve the execution of that task.

- Integration means the execution of this task in a way which is sensitive for the specific contents of the relationships in the network.

And this will sureiy be expressed in terms of a multiplicity of metaphors, of which the metaphorical limitations have to be recognised.

\section{Bibliography}

ADDLESON, M.S. 1988. General equilibrium and 'competition': On competition as strategy. (In Van Eeghen, P., ed., Reader for MACECH-J: Macro-Economics, Vol 2. Pretoria : Unisa. p 458-473.) [Also in: South African Journal of Economics, 52:156$171(1984)]$

BOTHA, ME. 1986. Metaphorical models and scientific realism. Southern African Journal of Philosophy, 5:83-87. [Also in Proceedings of the Philosophy of Science Association, 1986 Vol. 1. Dordrecht : Reidel p 374-383 ]

BOTHA, M E 1992 Elementêre inleiding tot die wetenskapsleer. Potchefstroom : Sentrale Publikasies, PU for CHE. (D 273/92.)

DARWIN, C 1906. The descent of man and selection in relation to sex. London : John Murray.

DARWIN, C. 1968 The origin of species by means of natural selection, or the preservation of favoured races in the struggle for life. Harmondsworth: Penguin Books.

DIJKSTERHUYS, E.J 1950. De mechanisering van het wereldbeeld. Amsterdam : Meulenhof

DOOYEWEERD, H 1957. A new critique of theoretical thought. Tr. by D.H. Freeman \& $\mathrm{H}$ de Jongste. Vol. III. Amsterdam : Paris.

FRIEDMAN, M. 1976. Milton Friedman in South Africa (In Feldberg, M., Jowell, K. \& Mulholland, S. eds. Cape Town : UCT (GSB). (Collected Public Addresses.)

HEIDEGGER, M. 1938. Die Zeit des Weltbildes. ( $m$ Holzwege. Frankfurt a.M. Klostermann. p. 69-104.)

HEIDEGGER, M. 1959 Das Wesen der Sprache. (In Unterwegs zur Sprache. Pfullingen : Neske. p 157-216.)

HOBBES, T. 1972 The citizen. (In Gert, B, ed. Man and citizen, Thomas Hobbes's De homine, tr. by C.T. Wood et al., and De cive. Tr. by Thomas Hobbes. Atlantic Highlands (NJ) : Humanities Press. p 87-386.)

HOBBES, T. 1972. On man. (In Gert, B. ed. Man and citizen, Thomas Hobbes's De homine Tr. by C.T. Wood et al, and De cive Tr. by Thomas Hobbes. Atlantic Highlands (NJ) : Humanities Press p. 33-85.)

HOOVER, K.D. 1988 Two types of monetarism. (In Van Eeghen, P. ed. Reader for MACECH-J: Macro-Economics, Vol 1. Pretoria : Unisa p. 181-199.) [Also in Journal of Economic Literature, 22:58-76 (1984). ] 
KANT, I. 1975. Mutmasslicher Anfang der Menschengeschichte (In Kant, I Werke in zehn Banden, Bd 9. Darmstadt: WBG. p 83-102.)

KANT, I. 1975. Idee zu einer allgemeine Geschichte in Weltburgerliche Absicht. (In Kant, I Werke in zehn Banden, Bd. 9 Darmstadt : WBG p 31-41.)

KEYNES, J.M. 1936. The general theory of employment, interest and money London : Macmillan.

KLAMER, A 1985 The New Classical macroeconomics. Conversations with the New Classical economists and their opponents Brighton, Sussex : Wheatsheaf Books (Harvester Press)

KUHN, T.S. 1975. The structure of scientific revolutions. Chicago : Univ of Chicago Press.

KUYPER, A. 1880. Soevereiniteit in eigen kring. Amsterdam : Hoveker.

MACHLUP, F. 1967. Theories of the firm: marginalist, behavioral, managerial. American Economic Review, 57:1-33.

MORPHEW, D. 1989. South Africa; the powers behind. Cape Town : Struik Christian Books.

MUSSOLINI, B 1935. Fascism: doctrines and institutions Rome : Ardita

ROUSSEAU, J J. 1916. Discourse on political economy. ( $/ n$ The social contract and other discourses. Tr. by G D Cole. London/Toronto/Paris/New York : Dent/Dutton p. 247-287.)

ROUSSEAU, J.J. 1916. The social contract ( $m$ The social contract and other discourses Tr. by G.D.H. Cole. London/Toronto/Paris/New York : Dent/Dutton. p. 3-124)

SANTEMA, J.H. 1978 Modellen in de wetenschap en de toepassing ervan. Historische en systematische beschouwing vanuit christelijk-wijsgerig perspectief. Delft: Delftse Universitaire Pers

SCHUURMAN, E. 1980. Technology and the future; a philosophical challenge. Toronto : Wedge.

SMITH, A. 1950. An enquiry into the nature and causes of the wealth of the nations $E d . \mathrm{E}$ Cannan London: Methuen

SMITH, A. 1976. The theory of moral sentiments The Glasgow edition of the works and correspondence of Adam Smith. Oxford : Clarendon

SMITH, A 1980. The principles which lead and direct philosophical enquiries illustrated by the history of astronomy. (In Wightman, W.P D. \& Bryce, J.C. eds. Adam Smith Essays on philosophical subjects. Oxford: Clarendon p 33-50.)

STERNHELL, Z. 1979. Fascist ideology. (In Laquer, W ed., Fascism: A reader's guide; Analyses, interpretations, bibliography, Harmondsworth : Penguin Books. p 325-408)

SUMNER, W.G 1934 Essays of W.G. Sumner II. Fd. by Keller \& Dawe. New Haven Yale Univ. Press

TRESMONTANT, C. 1991a. Les origines theosophiques du Nazisme. (In Tresmontant, C Problèmes de nötre temps: Chroniques Paris : OEIL. p. 268-273.)

TRESMONTANT, C. 199lb. Heidegger et le Nazisme. (In Tresmontant, C. Problèmes de nôtre temps: Chroniques. Paris: OEIL. p. 460-467.)

TORR, C. 1988 Equilibrium, expectations, and information. Oxford : Polity Press

VENTER, J.J 1992a From 'machine-world' to 'God-world' - world pictures and world views. Koers, 57:189-214

VENTER, J.J. 1992b Reason, survival, progress in eighteenth century thought Koers, 57:319-344.

VENTER, J.J 1994 World picture, individual, society (In Marx, L ed. Historicising the body politic: Nation and individual in the eighteenth century Proceedings of the second biennial conference of the Southern African Society for Eighteenth Century Studies, University of Cape Town, 8-11 September 1993. Cape Town : UCT. p 36-55) 
VENTER, J J 1995 Ontologie, representasie en metode (Hume, Hegel, Heidegger). In Viljoen H M. ed. Metodologie en representasie, Metodologiese implikasies van enkele representasie-opvattings vir die Literatuurstudie. Pretoria : RGN. p. 129-228.)

VENTER, J.J 1996 Conceiving conflict/competition - gripped by a world-picture: C. Darwin, D.H Lawrence and F.A von Hayek. (In Tiemieniecka, A T ed Analecta Husserliana, XLVIII. Amsterdam : Kluwer p. 205-247.)

VOLLENHOVEN, D.H.Th 1964 Isagoogé philosophiae. Amsterdam : VU Filosofisch Instituut.

VIEUX, S. 1994. In the shadow of neo-liberal racism. Race and Class, 36(1):23-32.

VON HAYEK, F.A. 1949. Individualism and the economic order. London : R \& KP.

VON HAYEK, F.A. 1952. The counter-revolution of science. Glencoe (Ill.) : Free Press.

YOUNG, R.M 1988. Darwin's metaphor: Nature's place in Victorian culture. Cambridge CUP. 